\title{
Disease Response Assessment Character Result in Standard Format
}

National Cancer Institute

\section{Source}

National Cancer Institute. Disease Response Assessment Character Result in Standard

Format. NCl Thesaurus. Code C117403.

The standard character or string for representation and reporting of disease response data. 